\title{
Optimisation of Catechol Removal from Aqueous Solution by Adsorption on Activated Carbon from Corn Cobs and Coffee Husk
}

\author{
PATRICIA NGUEMJOM NONO ${ }^{1}$, THÉOPHILE KAMGAING ${ }^{1 *}$, DONALD RAOUL \\ TCHUIFON TCHUIFON ${ }^{1}$, and SOLOMON ANAGHO GABCHE ${ }^{1,2}$
}

${ }^{1}$ Laboratory of Noxious Chemistry and Environmental Engineering, Department of Chemistry, Faculty of Science, University of Dschang, P.B Box 67, Dschang, Cameroon ${ }^{2}$ Department of Chemistry, University of Bamenda, P.O. Box, 39, Bamenda, Cameroon theophile.kamgaing@univ-dschang.org

Received 29 March 2016 / Accepted 14 April 2016

\begin{abstract}
Activated carbons prepared by chemical activation of corn cobs and coffee husks, using $\mathrm{H}_{3} \mathrm{PO}_{4}$ were characterized for its moisture content, bulk density, $\mathrm{pH}$ of zero point charge $\left(\mathrm{pH}_{\mathrm{pcz}}\right)$ and $\mathrm{pH}$. Batch adsorption of catechol from aqueous solution using the characterized activated carbons was investigated. The adsorption properties were studied in terms of $\mathrm{pH}$, equilibrium time, initial concentration $\left(\mathrm{C}_{0}: 10-110 \mathrm{mg} / \mathrm{L}\right)$ and adsorbent mass. The experimental data fitted well the pseudo second order kinetic model while the equilibrium isotherm data fitted the Langmuir model. The results indicate that activated carbons obtained from the chemical activation of corn cobs and coffee husks are suitable adsorbents for the removal of catechol from aqueous solution.
\end{abstract}

Keywords: Adsorption, Corncobs, Coffee husks, Activated carbon, Catechol

\section{Introduction}

Phenolic compounds are toxic and carcinogenic in nature. They are among the priority pollutants of the European Union and US Environmental Protection Agency ${ }^{1}$.These compounds are important organic intermediates for the industry and agriculture. For example, hydroxy aromatic compounds, such as catechol, resorcinol and hydroquinone were used widely as industrial solvents. Catechol (1,2-dihydroxybenzene) is also widely used to produce food additive agents, hair dyes, and antioxidants ${ }^{2}$. The effluents from synthetic coal fuel conversion processes may contain catechol concentrations ranging from 1 to $1,000 \mathrm{mg} / \mathrm{L}^{3}$.

The toxicity of phenol and its derivatives to microorganisms has been demonstrated in the past years ${ }^{4}$ and has been suggested to be the reason for the difficulties in cultivating microorganisms on benzene, toluene, or chlorobenzene ${ }^{5}$. Several studies indicated the toxicity of these compounds to water flea, zebra fish, trout, rabbit, cat, rat, mouse and for 
human cell lines. They are strongly irritating to the eyes, skin and respiratory tract and have been proven to cause DNA damage, vascular collapse, coma and death ${ }^{6}$. However, these phenolic compounds are considered as the primary pollutants in wastewater due to their high toxicity, high oxygen demand and low biodegradability ${ }^{7}$. Consequently, their removal from wastewater has attracted significant environmental concerns.

Conventional methods used in the remediation/degradation of catechol are biodegradation $^{8}$, anaerobic biodegradation ${ }^{9}$, anodic oxidation ${ }^{10}$, photocatalysis $^{11}$ and oxidative catalysis ${ }^{12}$. Adsorption techniques have gained favor in recent years because they are considered efficient for the removal of trace organic pollutants from water that cannot be removed using other treatment processes ${ }^{13}$.

The United States Environmental Protection Agency (USEPA) has designated granular activated carbon (GAC) adsorption as the 'best available technology' for removing organic pollutants ${ }^{14}$. They are materials with large specific surface areas, high porosity, adequate pore size distribution and high mechanical strength ${ }^{15}$. Activated carbons can be produced from different carbonaceous materials such as coal, wood, peat and agricultural wastes especially lignocellulosic by-products. They are widely employed in water and wastewater treatment processes for removing organic compounds such as phenol and its derivatives ${ }^{16}$.

Corn and coffee cultivation occupy a strategic position within the agricultural sector in the world ${ }^{17}$. Their high production rate implies that a huge quantity of corn cobs and coffee chaff are generated. Due to their abundance and their diversity, these agricultural wastes constitute a source of renewable raw materials. They can be used to produce activated carbon characterized by a high surface area, developed micropores and heterogeneous functional groups.

The aim of this study was to investigate the kinetics and the equilibrium aspects of the adsorption of catechol onto the activated carbon from corn cobs and coffee husks. Three kinetics models including pseudo-second order, Elovich and intra-particle diffusion models will be used to deduce the adsorption mechanisms. Experimental equilibrium isotherms will be fitted with Langmuir, Freundlich, Temkin and Dubinin-Radushkevich equations to analyze the adsorption process.

\section{Experimental}

Corn cobs were collected at the farm of the Faculty of Agronomy and Agricultural Science, University of Dschang-Cameroon. Coffee husks came from a coffee factory based in Santchou, West Cameroon. Activated carbons were prepared from corn cobs and coffee chaff by chemical activation with orthophosphoric acid $\left(\mathrm{H}_{3} \mathrm{PO}_{4}\right)$, according to the method developed by Tchakala et al. ${ }^{18}$. Initially, the precursor was washed thoroughly with water, dried and then impregnated with 40\% dilute orthophosphoric acid solution for 6 hours at $120{ }^{\circ} \mathrm{C}$ in an oven. The resulting materials were washed with distilled water to remove any leachable impurities. The dried solid was carbonized in an electric furnace. The optimized carbonization time and temperature were $2 \mathrm{~h}$ and $450{ }^{\circ} \mathrm{C}$ respectively. The activated carbons were labeled $\mathrm{CC}$ and $\mathrm{CH}$ when obtained from corncobs and coffee husks respectively.

Characterization of the activated carbons

\section{Determination of $\mathrm{pH}_{p z c}$}

The point of zero charge $\left(\mathrm{pH}_{\mathrm{pzc}}\right), \mathrm{pH}$ at which the adsorbent is neutral in aqueous suspension, was determined following the procedure of Lopez-Ramon ${ }^{19}$. 


\section{Determination of iodine number}

Iodine number is defined as the number of milligrams of iodine $0.1 \mathrm{~N}$ adsorbed from an aqueous solution by $1 \mathrm{~g}$ of activated carbon. This value was determined following the procedure of ASTM, AWWA ${ }^{20}$.

\section{Bulk density}

The bulk density is defined as the mass of a unit volume of the sample in air including both the pore system and the void between the particles. In fact, a $25 \mathrm{~cm}^{3}$ specific gravity bottle was weighed empty and later carefully filled to the mark with powdered activated carbon. The bulk density was calculated from the equation:

$$
\text { Bulkdensity }=\frac{\text { Weight of power }}{25}
$$

\section{Moisture content}

The oven drying method, used when water is the only volatile material present in the activated carbon was determined following the procedure of $\mathrm{ASTM}^{21}$.

pH value

When $50 \mathrm{~mL}$ of distilled water was added to 1 gram of activated carbon and the mixture stirred for 24 hours, the filtrate $\mathrm{pH}$ is considered that of activated carbon.

\section{IR of activated carbon}

Infrared (IR) spectroscopy gives the different functional groups that are present at the surface of materials. The two biosorbents were analyzed using a FTIR Bruker Alpha Fourier transformed infra-red spectrophotometer (FT-IR).

\section{Reagents}

\section{Catechol}

Analytical reagent (purity $>99 \%$ ), was used as the adsorbate. A stock solution was prepared by dissolving $550 \mathrm{mg}$ of catechol in $50 \mathrm{~mL}$ of distilled water. Different initial concentrations were obtained by successive dilutions. Catechol concentration were determined by UV absorption at $276 \mathrm{~nm}$ wavelength using a calibrated UV-Visible spectrophotometer (Jenway model 6715).

\section{Batch adsorption}

Experiments were carried out by dispersing known quantities of adsorbent $(0.1-1.1 \mathrm{~g})$ in $10 \mathrm{~mL}$ of $10-110 \mathrm{mg} / \mathrm{L}$ catechol solution in $100 \mathrm{~mL}$ flasks. The mixture was shaken for a known time, the solution filtered, and the residual concentrations of catechol determined by spectrophotometry. The amount of catechol adsorbed was obtained using the following equation:

$$
Q_{t}=\frac{\left(C_{o}-C_{t}\right) v}{m}(m g / g)
$$

Where $\mathrm{C}_{0}$ and $\mathrm{C}_{\mathrm{t}}$ are the concentrations of catechol solution $(\mathrm{mg} / \mathrm{L})$ at initial and final time ( $\mathrm{t}$ ) respectively; $\mathrm{V}$ the volume of solution $(\mathrm{L})$ and $\mathrm{m}$ is the weight $(\mathrm{mg})$ of activated carbon. Each experiment was carried twice and the average results are presented. 
To evaluate the effect of $\mathrm{pH}$ on the adsorption of catechol by activated carbon was investigated over a pH range of 2 to 14 at $25{ }^{\circ} \mathrm{C}$ with an initial solute concentration of $55.55 \mathrm{mg} / \mathrm{L}$ and an adsorbent amount of $0.1 \mathrm{~g}$. Experiments were carried out at constant stirring speed of $150 \mathrm{rpm} / \mathrm{min}$. The $\mathrm{pH}$ of the medium was adjusted by adding diluted solutions of $0.1 \mathrm{M} \mathrm{HCl}$ or $0.1 \mathrm{M} \mathrm{NaOH}$.

The type of equilibrium for the adsorption process was obtained by fitting the experimental data on the Langmuir, Freundlich, Temkin and Dubinin-Radushkevich (D-R) isotherms.

\section{Langmuir isotherm}

According to the theory of adsorption, the model of Langmuir is based on the fixation of a monolayer of adsorbate molecules on the pores surface ${ }^{22}$. The model assumes uniform adsorption on the surface and no transmigration in the plane of the surface. Langmuir's equation is mathematically expressed as follows;

$$
Q_{e}=\frac{Q_{\max } C_{e} K_{L}}{1+C_{e} K_{L}}
$$

Where $\mathrm{K}_{\mathrm{L}}(\mathrm{L} / \mathrm{mg})$ is the equilibrium adsorption constant and is related to the free energy of the adsorption; $\mathrm{Q}_{\max }(\mathrm{mg} / \mathrm{g})$, the maximum adsorption capacity; $\mathrm{C}_{\mathrm{e}}$, the equilibrium concentration and $\mathrm{Q}_{\mathrm{e}}(\mathrm{mg} / \mathrm{g})$ the amount of the catechol adsorbed at equilibrium. The linear form of equation 3 is given by equation 4 :

$$
\frac{1}{Q_{e}}=\frac{1}{Q_{\max }}+\frac{1}{C_{e} K_{L} Q_{\max }}
$$

\section{Freundlich isotherm}

The Freundlich model is an empirical equation that considers heterogeneous adsorptive energies on the adsorbent surface ${ }^{23}$.

$$
Q_{e}=K_{F} C_{e}^{1 / n}
$$

The linear form of equation 5 is given by equation 6 :

$$
\ln Q_{e}=\frac{1}{n} \ln C_{e}+\ln K_{F}
$$

Where $\mathrm{K}_{\mathrm{F}}(\mathrm{L} / \mathrm{g})$ and $1 / \mathrm{n}$ are Freundlich constants.

\section{Temkin isotherm}

The Temkin model is generally applied in the form ${ }^{24}$ :

$$
Q_{e}=Q_{m} \frac{R T}{\Delta Q} \ln K_{T} C_{e}
$$

Where $Q_{e}$ is the amount of catechol adsorbed at equilibrium, $K_{T}$ is the equilibrium constant and $\Delta \mathrm{Q}$ is the energy of adsorption. The linear form of this equation is:

$$
Q_{e}=Q_{m} \frac{R T}{\Delta Q} \ln K_{T}+Q_{m} \frac{R T}{\Delta Q} \ln C_{e}
$$




\section{Dubinin-Radushkevich isotherm}

The Dubinin-Radushkevich (D-R) isotherm model was applied to the data in order to deduce the heterogeneity of the surface energies of adsorption and the characteristic porosity of the adsorbent ${ }^{25}$. The linear form of the $\mathrm{D}-\mathrm{R}$ isotherm is given in equation 9 .

$$
\operatorname{Ln} \mathrm{Q}_{\mathrm{e}}=\ln \mathrm{Q}_{\mathrm{D}}-\mathrm{B}_{\mathrm{D}}\left[\mathrm{RT} \ln \left(1+1 / \mathrm{C}_{\mathrm{e}}\right)\right]^{2}
$$

The apparent energy of adsorption, $\mathbf{E}$ was calculated using equation 10.

$$
\mathrm{E}=1 /\left(2 \mathrm{~B}_{\mathrm{D}}\right)^{1 / 2}
$$

The constants $Q_{D}(\mathrm{~mol} / \mathrm{g})$ is the $\mathrm{D}-\mathrm{R}$ constant representing the theoretical saturation capacity and $B_{D}\left(\mathrm{~mol}^{2} / J^{2}\right)$ is a constant related to the mean free energy of adsorption per mole of the adsorbate, $\mathrm{R}$ is the ideal gas constant, $(8.314 \mathrm{~J} / \mathrm{mol} \mathrm{K}), \mathrm{T}(\mathrm{K})$ is the temperature of adsorption and $\mathrm{E}(\mathrm{kJ} / \mathrm{mol})$ is the mean free energy of adsorption per molecule of the adsorbate when transferred to the surface of the solid from infinity in the solution ${ }^{26}$.

\section{Kinetics of adsorption}

The kinetics of the adsorption was studied at various initial concentrations of catechol. At regular time intervals, the residual catechol in the filtrates was measured. The amount of catechol adsorbed on activated carbon at time $t, Q_{t}(\mathrm{mg} / \mathrm{g})$, was calculated using the following equation:

$$
Q_{t}=\frac{\left(C_{0}-C_{t}\right) V}{m}(m g / g)
$$

Where $\mathrm{C}_{0}$ and $\mathrm{C}_{\mathrm{t}}$ are the concentrations of catechol solution $(\mathrm{mg} / \mathrm{L})$ at initial and final time (t) respectively; $\mathrm{V}$ the volume of solution $(\mathrm{L})$ and $\mathrm{m}$ is the weight $(\mathrm{mg})$ of activated carbon. Each experiment was carried out twice and the average results are presented. Kinetic models used to fit the experimental data are: the pseudo-second order, Elovich models and intraparticle diffusion.

\section{Pseudo-second order model}

The kinetic data are fitted to the pseudo-second order model resulting in the following linear equation $^{27}$ :

$$
\frac{t}{Q_{t}}=\frac{1}{K_{2} Q_{e}}+\frac{1}{Q_{e}} t
$$

Where $\mathrm{K}_{2}$ is the pseudo-second order rate constant.

\section{Intra-particle diffusion}

Intra-particle diffusion is often considered as the limiting step which controls the kinetics of most processes of adsorption. The possibility of a limitation by diffusion in the pores is explored by plotting catechol uptake against the square root of time, using the Weber and Morris model ${ }^{28}$ :

$$
Q_{t}=K_{d} t^{1 / 2}+C
$$

Where $\mathbf{Q}_{\mathbf{t}}$ is the instantaneous amount of catechol adsorption per unit gram of activated carbon (mg/g), C is a constant which gives an idea about the thickness of the boundary layer.

\section{Elovich kinetic equation}

The Elovich equation is generally expressed $\mathrm{as}^{29}$ : 


$$
\frac{d Q_{t}}{d t}=\alpha e^{-\beta Q t}
$$

Where $Q_{t}(\mathrm{mg} / \mathrm{g})$ is the sorption capacity at time $\mathrm{t}, \alpha$ is the initial adsorption rate $(\mathrm{mg} / \mathrm{g} \cdot \mathrm{min})$ and $\beta$ is the desorption rate constant $(\mathrm{mg} / \mathrm{g} . \mathrm{min})$ during any one experiment. The integrated and simplified equation (assuming that $\alpha \beta t>>1$ ) is:

$$
Q_{t}=\frac{1}{\beta} \ln (\alpha \beta)=\frac{1}{\beta} \ln t
$$

\section{Results and Discussion}

\section{Characterization of activated carbon}

Table 1 gives the properties of the activated carbons produced in this study.

Table 1. Characterization of adsorbents

\begin{tabular}{ccccc}
\hline Sample & $\begin{array}{c}\text { Bulk density, } \\
\mathrm{kg} / \mathrm{m}^{3}\end{array}$ & $\begin{array}{c}\text { Moisture } \\
\text { content, \% }\end{array}$ & $\mathrm{pH}$ & $\mathrm{pH}_{\mathrm{pcz}}$ \\
\hline $\mathrm{CC}$ & 365.2 & 10 & 3.00 & 3.17 \\
$\mathrm{CH}$ & 581.2 & 18 & 3.27 & 3.04 \\
\hline
\end{tabular}

Bulk densities of the activated carbons prepared in this investigation are $365.2 \mathrm{~kg} / \mathrm{m}^{3}$ and $581.2 \mathrm{~kg} / \mathrm{m}^{3}$ respectively for $\mathrm{CC}$ and $\mathrm{CH}$. This means that, the mass of a unit volume of CC in air including both the pore system and the voids between the particles is smaller than the one of $\mathrm{CH}$. The two activated carbons present an acid $\mathrm{pH}$ value and an acid point of zero charge.

\section{Iodine number}

The iodine number (IN) in Table 2 measures the adsorption of iodine from an aqueous solution. It is one of the most fundamental parameters used to characterize the performance of activated carbons. High values of iodine number indicate high degree of activation. It is a measure of the micropores and it is used as an indication of the total surface area. The iodine numbers of the activated carbons prepared in this investigation are 447.7 and 457.2 respectively for $\mathrm{CC}$ and $\mathrm{CH}$. These values indicate that the two activated carbons perform better in removing small sized contaminants. Table 2 compares iodine numbers of the present work with other known iodine numbers.

Table 2. Iodine number values of the samples

\begin{tabular}{lcc}
\hline Samples & Iodine numbers, $\mathrm{mg} / \mathrm{g}$ & [References] \\
\hline $\mathrm{CC}$ & 447.7 & Present work \\
$\mathrm{CH}$ & 457.2 & Present work \\
Commercial activated carbon & 585.000 & {$[30]$} \\
Cassava peel activated carbon & 306.400 & {$[31]$} \\
Rice husk activated carbon & 495.3 & {$[32]$} \\
Coffee husk activated carbon & 476.25 & {$[32]$} \\
Rice and coffee husk activated carbon & 590.55 & {$[32]$} \\
Cola acuminate carbon & 656.71 & {$[33]$} \\
\hline
\end{tabular}

\section{Infra-red analysis}

Figure 1 gives the FTIR-spectra of corn cobs and coffee husks before carbonization and Figure 2 represents the FTIR-spectra of the two activated carbons $\mathrm{CC}$ and $\mathrm{CH}$. 


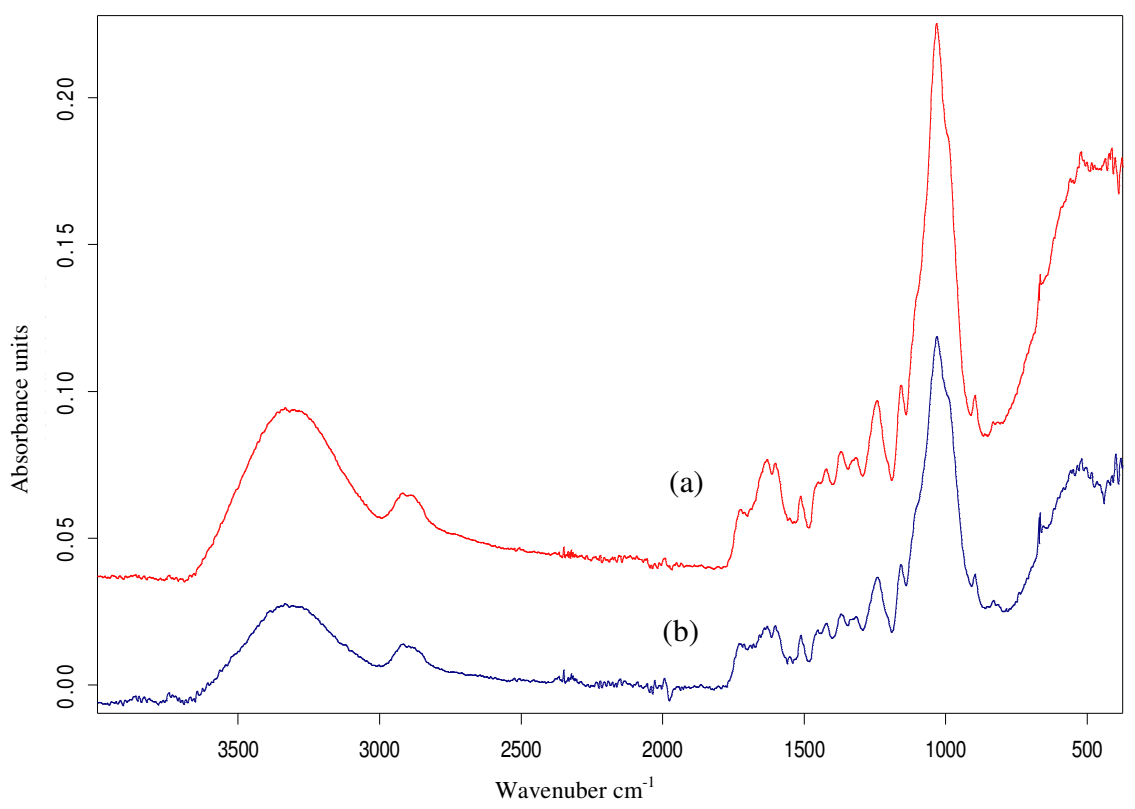

Figure 1. FTIR spectra of corn cobs (a) and coffee husk (b)

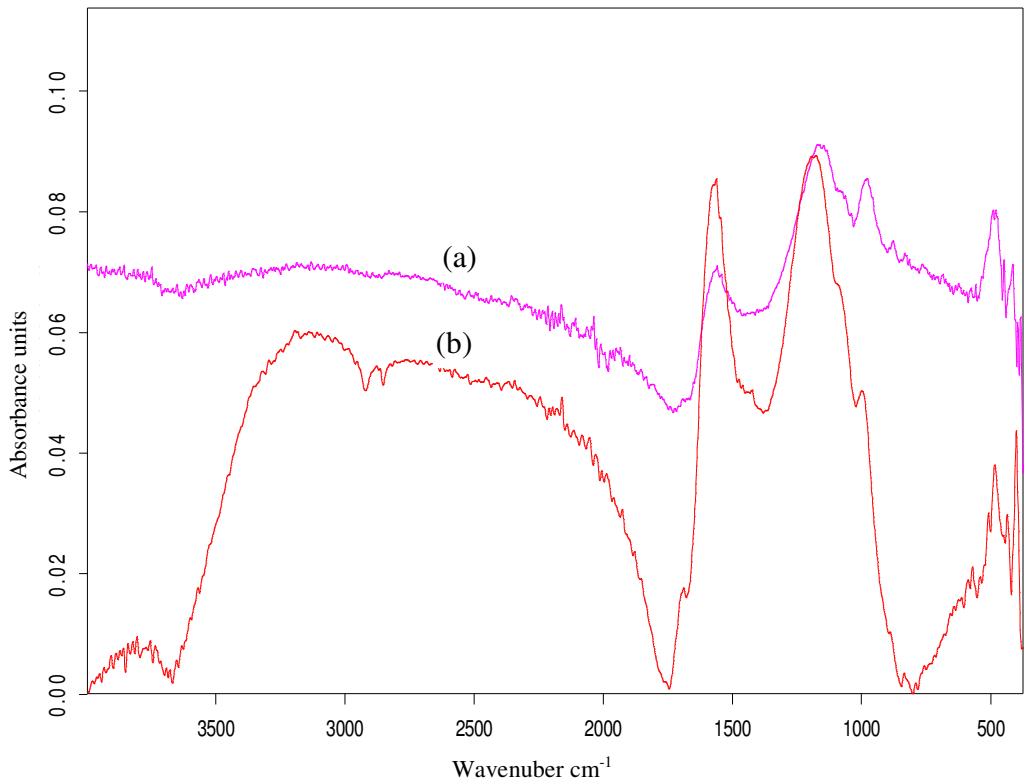

Figure 2. FTIR spectra of activated carbons: (a) corn cobs (CC) and (b) coffee husk (CH)

These spectra are similar to each other. This means that they have similar functional groups at their surfaces. The $\mathrm{O}-\mathrm{H}$ stretching vibration bands seen in the wavenumber range of $3600-3200 \mathrm{~cm}^{-1}$ indicate the presence of surface hydroxyl groups of alcohol, water and polysaccharides in the two raw material samples. The presence of absorption bands characteristic of $\mathrm{CH}$, or $\mathrm{CH}_{2}$ structures $\left(2900-2800 \mathrm{~cm}^{-1}\right.$ and $\left.1400-1300 \mathrm{~cm}^{-1}\right)$ in all the 
spectra suggests the existence of some aliphatic species. The presence of bands in the range $1700-1500 \mathrm{~cm}^{-1}$ can be attributed to the stretching vibrations of $\mathrm{C}=\mathrm{O}$ in carboxylics, esters, lactones, quinones and/or ion radical structures. Also, the $1730 \mathrm{~cm}^{-1}$ adsorption bands was attributed to $\mathrm{C}=\mathrm{C}$ of alkene and carboxylate structures. The absorption bands in the 1750 $1700 \mathrm{~cm}^{-1}, 1650-1610 \mathrm{~cm}^{-1}$ and $1570-1520 \mathrm{~cm}^{-1}$ regions are due to aromatic rings and double bond vibrations. The C-O single bond shows an adsorption band ${ }^{34}$ at about $1030 \mathrm{~cm}^{-1}$.

Table 3. Functional groups and their attributions of corn cobs and coffee husk

\begin{tabular}{cc}
\hline Wave length $\mathrm{cm}^{-1}$ & Attribution \\
\hline $3600-3200$ & $-\mathrm{OH}$ \\
$2900-2800,1400-1300$ & $-\mathrm{CH},-\mathrm{CH}_{2}$ \\
$1700-1500$ & $-\mathrm{C}=\mathrm{O}$ \\
1730 & $-\mathrm{C}=\mathrm{C}$ \\
$1750-1700,1650-1610,1570-1520$ & Aromatics rings \\
1030 & $\mathrm{C}-\mathrm{O}$ \\
\hline
\end{tabular}

The FTIR spectra of the activated carbons are shown in Figure 2. At $3258 \mathrm{~cm}^{-1}$ (spectrum b) a $\mathrm{O}-\mathrm{H}$ stretching band, due to the existence of surface hydroxyl groups was observed. The presence of absorption bands characteristic of $\mathrm{CH}$ or $\mathrm{CH}_{2}$ structures (2800$2900 \mathrm{~cm}^{-1}$ and $400-460 \mathrm{~cm}^{-1}$ ) in all the spectra suggests the existence of some aliphatic species in the activated carbons ${ }^{35}$. The presence of bands at $1645 \mathrm{~cm}^{-1}$ (b) can be attributed to the stretching vibrations of $\mathrm{C}=\mathrm{O}$ in carboxylic acids. Another broad band in the 1570 $1680 \mathrm{~cm}^{-1}$ range consisting of a series of overlapping absorption bands that can be ascribed to $\mathrm{C}=\mathrm{C}$ of aromatics ring ${ }^{36}$. The overlapping peaks which form an absorption band in the $1300-1000 \mathrm{~cm}^{-1}$ region, can be assigned to C-O of carboxylics acid, phenolic structures and esters. After the activation with $\mathrm{H}_{3} \mathrm{PO}_{4}$, the peak at the $3600-3200 \mathrm{~cm}^{-1}$ range of the precursor, becomes weaker indicating the disappearance of water molecules. Several new peaks are detected in the region of $752-872 \mathrm{~cm}^{-1}$. There might also be phosphorus containing groups ${ }^{37}$.

\section{Adsorption studies}

\section{Effect of initial $\mathrm{pH}$ on the adsorption}

The $\mathrm{pH}$ of solution is one of the most important parameters affects the catechol adsorption process, because it affects the surface charge of the adsorbent as well as the degree of ionization and speciation of catechol ${ }^{38}$. The effect of initial $\mathrm{pH}$ on the adsorption of catechol was studied with initial catechol concentration of $55.55 \mathrm{mg} / \mathrm{L}$ and optimum carbon amount of $0.1 \mathrm{~g}$. Figure 3 shows the influence of solution $\mathrm{pH}$ on catechol removal by $\mathrm{CC}$ and $\mathrm{CH}$ in the $\mathrm{pH}$ range 2.0 to 14.0 . The result shows that the quantity of catechol adsorbed increased from 2 to 8 ; and then decreased sharply from $\mathrm{pH}$ greater than 10 . The maximum catechol uptake obtained at $\mathrm{pH}=8$ and $\mathrm{pH}=10$ can be explained by the fact that at this $\mathrm{pH}$ range, more protonated species are present in the solution. At $\mathrm{pH} 11$, the repulsive electrostatic forces predominate, and the adsorption at low concentrations is less than that at high concentrations.

\section{Effect of contact time}

The effect of contact time on the removal of catechol is reported in Figure 4 and the result indicates that the equilibrium time was reached after about 35 minutes. Two kinetics regions were observed: the first ( $0-15$ minutes) is characterized by a high adsorption rate and this is due to the fact that initially the number of sites of activated carbon available is higher and the driving force for the mass transfer is greater. In the second region (15-35 minutes), as the time progresses, the number of free sites on the activated carbon decreases, and the non-adsorbed molecules are assembled at the surface, thus limiting the adsorption capacity and the rate. 


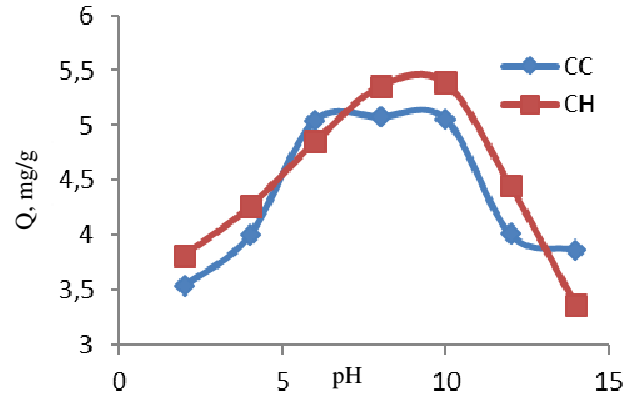

Figure 3. Effect of $\mathrm{pH}$ on the uptake of catechol onto activated carbons (room temperature, $55.55 \mathrm{mg} / \mathrm{L}$ initial concentration)

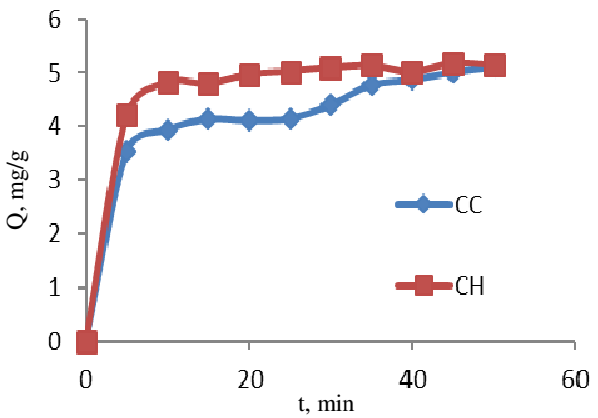

Figure 4. Effect of contact time on the uptake of catechol onto activated carbons (room temperature, $55.55 \mathrm{mg} / \mathrm{L}$ initial concentration)

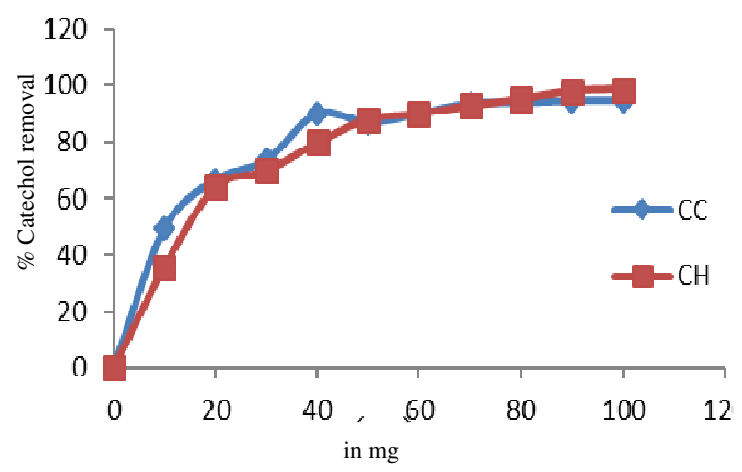

Figure 5. Effect of amount of adsorbent on the uptake of catechol onto activated carbons (room temperature, $55.55 \mathrm{mg} / \mathrm{L}$ initial concentration)

\section{Effect of amount of adsorbent}

Another parameter that controls adsorption is the amount of activated carbon employed. Under selected conditions (stirring time, 35 minutes and catechol concentration $55.55 \mathrm{mg} / \mathrm{L}$ ), the amount of activated carbon was varied from $10 \mathrm{mg}$ to $110 \mathrm{mg}$. Figure 5 indicates that the adsorption amount increases as the amount of activated carbon increases. This is due to the fact that, an increase in the mass increases the number of sites of adsorption on the surface of the adsorbent. At $110 \mathrm{mg}$ of activated carbon, almost $98.72 \%$ of the catechol was removed from solutions by $\mathrm{CP}$ and $94.67 \%$ by CR. It can note that the adsorbent $\mathrm{CP}$ has a greater percentage of elimination than CR. Hence, for subsequent studies, $100 \mathrm{mg}$ of activated was used.

\section{Kinetics study}

Chemical kinetics is a useful method not only for the determination of the rate of the reaction but also for the elucidation of the reaction mechanism ${ }^{40}$. To evaluate the kinetic mechanism that controls the adsorption process of catechol on the activated carbons, the pseudo-second order, Elovich model and intra-particle diffusion model were tested to interprete the experimental data. The results of the kinetics parameters are shown in Table 4. The plots of these kinetic models are presented in Figures 6 to 8 . 
Table 4. Parameters of kinetic models for catechol adsorption on $\mathrm{CC}$ and $\mathrm{CH}$

\begin{tabular}{cccc}
\hline Adsorbent & Parameters & $\mathrm{CC}$ & $\mathrm{CH}$ \\
\hline & $\mathrm{K}_{2}, \mathrm{~g} / \mathrm{min} . \mathrm{mg}$ & 0.907 & 0.227 \\
Pseudo-second order & $\mathrm{Q}_{\mathrm{e}}, \mathrm{mg} / \mathrm{g}$ & 5.464 & 5.263 \\
& $\mathrm{H}, \mu \mathrm{mol} / \mathrm{g} / \mathrm{min}$ & 27.082 & 6.2877 \\
& $\mathrm{R}^{2}$ & 0.987 & 0.999 \\
Intraparticle diffusion & $\mathrm{K}_{\mathrm{id}}, 1 / \mathrm{min}$ & 0.316 & 0.157 \\
& $\mathrm{X}_{\mathrm{i}}$ & 2.81 & 4.144 \\
& $\mathrm{R}^{2}$ & 0.940 & 0.754 \\
Elovich & $\mathrm{B}, \mathrm{g} / \mu \mathrm{mol}$ & 1.5060 & 2.7624 \\
& $\mathrm{~A}, \mu \mathrm{mol} / \mathrm{g} / \mathrm{min}$ & 22.19 & 13190.24 \\
& $\mathrm{R}^{2}$ & 0.884 & 0.859 \\
\hline
\end{tabular}

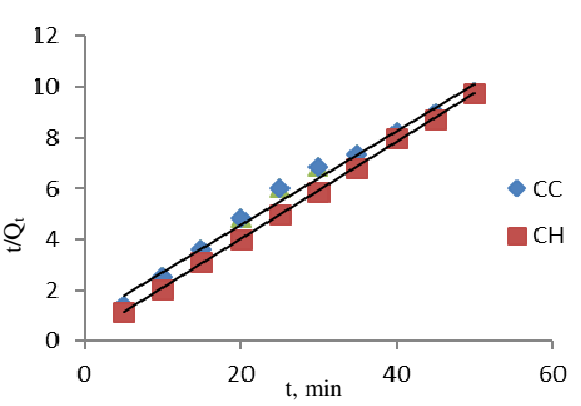

Figure 6. Linearized pseudo-second order plots

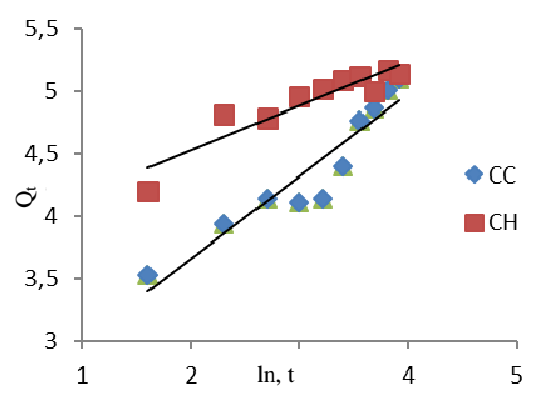

Figure 7. Linearized Elovich plots

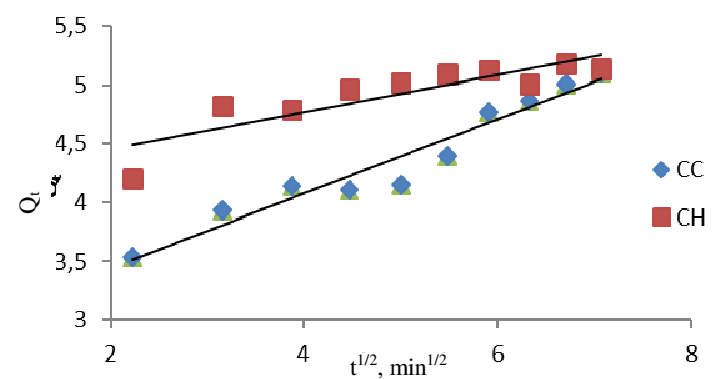

Figure 8. Linearized Intra-partıcle diffusion plots

Comparing the correlation coefficients from the various kinetic models, the pseudo second-order gives the highest values. This indicates that catechol adsorption onto activated carbons follows the pseudo-second order model with $\mathrm{R}^{2}$ values of 0.987 and 0.999 respectively for $\mathrm{CC}$ and $\mathrm{CH}$. Thus, it can be concluded that the rate limiting step for the adsorption of catechol is chemisorption, involving forces caused by the sharing of electrons between activated carbon and catechol ${ }^{41}$.

\section{Equilibrium isotherm modeling}

The adsorption isotherm was obtained from data deduced from the effect of initial catechol concentration. These isotherms are generally used to establish the relationship between the amount of pollutant adsorbed and its equilibrium concentration in solution. Although these isotherms do not lead to the deduction of the adsorption mechanisms, they are useful for comparing results from different sources on a quantitative basis, providing information on the adsorption potential of a material with easily interpretable constants. 
The Langmuir, Freundlich, Dubinin-Radushkevich and Temkin isotherms were applied in this study; the parameters of the adsorption isotherms are shown in Table 5 and the plots are given in Figures 9 to 12. The results show that the Langmuir isotherm with $\mathrm{R}^{2}$ values of 0.981 and 0.994 respectively for $\mathrm{CC}$ and $\mathrm{CH}$, is the most appropriate model for the catechol adsorption. This suggests that the adsorption of catechol molecules covers a monolayer of the carbon surface.

Table 5. Parameters of isotherms adsorption of catechol on $\mathrm{CC}$ and $\mathrm{CH}$

\begin{tabular}{cccc}
\hline Adsorbent & Parameters & $\mathrm{CC}$ & $\mathrm{CH}$ \\
\hline \multirow{3}{*}{ Dubinin-Radushkevich } & $\mathrm{Q}_{\mathrm{m}}, \mu \mathrm{mol} / \mathrm{g}$ & 469.53 & 284.8 \\
& $\mathrm{E}, \mathrm{J} / \mathrm{mol}$ & 10000 & 22.36 \\
& $\mathrm{R}^{2}$ & 0.906 & 0.929 \\
Freundlich & $1 / \mathrm{n}$ & 0.691 & 0.239 \\
& $\mathrm{~K}_{\mathrm{f}}, \mathrm{L} / \mathrm{g}$ & 4.825 & 30.63 \\
& $\mathrm{R}^{2}$ & 0.956 & 0.978 \\
Langmuir & $\mathrm{K}_{\mathrm{L}}, \mathrm{L} / \mathrm{mg}$ & 1.49 & 1.066 \\
& $\mathrm{R}^{2}$ & 0.981 & 0.994 \\
& $\mathrm{Q}_{\mathrm{m}}, \mu \mathrm{mol} / \mathrm{g}$ & 200 & 90.90 \\
& $\Delta \mathrm{Q}, \mathrm{J} / \mathrm{mol}$ & 11690 & 17.73 \\
Temkin & $\mathrm{K}_{\mathrm{T}}$ & 0.142 & 9.02 \\
& $\mathrm{R}^{2}$ & 0.868 & 0.907 \\
\hline
\end{tabular}
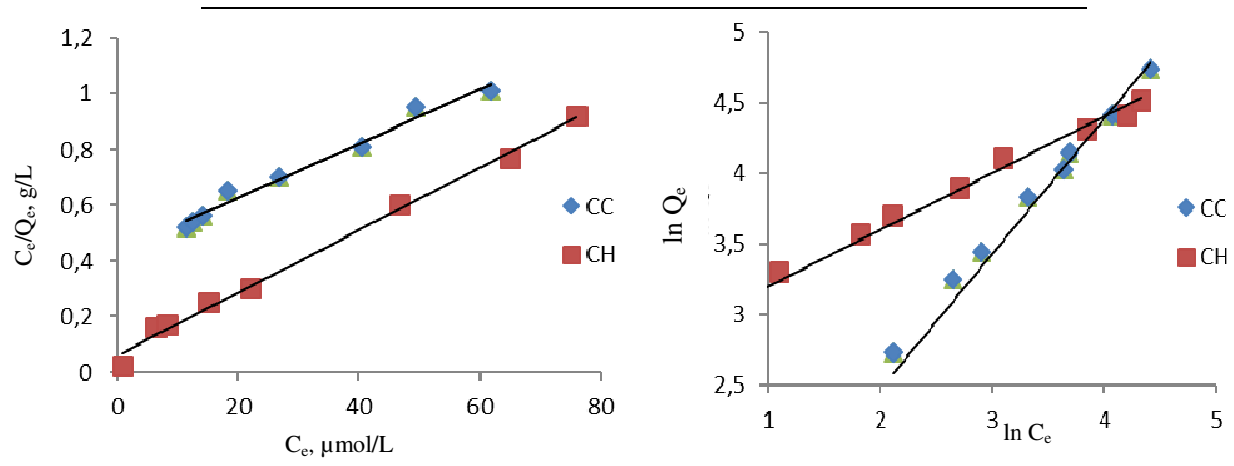

Figure 9. Linear plot Langmuir of the model

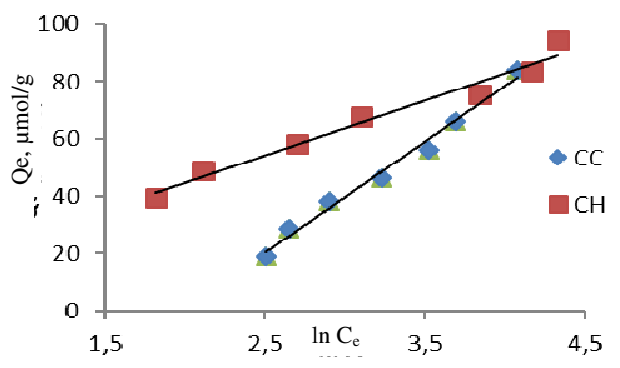

Figure 10. Linear plot of the Freundlich model

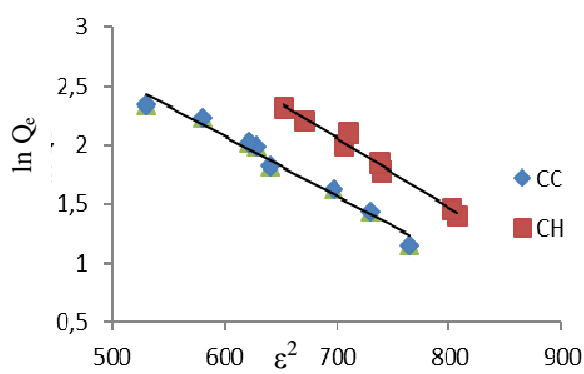

Figure 11. Linear plot of the Temkin model

Figure 12. Linear plot of the DubininRadushkevich model 


\section{Conclusion}

In this study, two activated carbons obtained from coffee husks and corn cobs using $\mathrm{H}_{3} \mathrm{PO}_{4}$ were evaluated as adsorbents for the removal of catechol from an aqueous solution. The biosorption experiments were performed as a function of adsorbent dosage, $\mathrm{pH}$, contact time, and initial concentration. The percentage of removal decreased with an increase in the initial concentration and increased with increasing contact time and dose of the adsorbent. Furthermore, the kinetics of the biosorption studies were fitted to a pseudo-second-order kinetic model at different concentrations. The equilibrium data were well-expressed by the Langmuir isotherm model. The present study suggests that activated carbon from corncobs and coffee husks is a low-cost and environmental friendly adsorbent that may be used for the removal of catechol from aqueous solutions.

\section{References}

1. Santana C M, Ferrera Z S, Torres P M E and Santana J J, Molecules, 2009, 14(1), 298-320; DOI:10.3390/molecules14010298

2. Dellinger B, Pryor W A, Cueto R, Squadrito G L, Hegde V and Deutsch W A, Chem Res Toxicol., 2001, 14(10), 1371-1377; DOI:10.1021/tx010050x

3. Phutdhawong W, Chowwanapoonpohn S and Buddhasukh D, Anal Sci., 2000, 16(10), 1083-1084; DOI:10.2116/analsci.16.1083

4. Schweigert N, Zehnder A J B and Eggen R I L, Environ Microbiol. , 2001, 3(2), 81-91; DOI:10.1046/j.1462-2920.2001.00176.x

5. Boyd G E, Adamson A W and Meyers L S, J Am Chem Soc., 1947, 69(11), 28362848; DOI:10.1021/ja01203a066

6. Rahouti M, Steiman R, Seigle-Murandi F and Chritov L P, Chemosphere, 1999, 38(11), 2549-2559; DOI:10.1016/S0045-6535(98)00462-7

7. Van Duursen M B M, Sanderson J T, de Jong P C, Kraaij M and van den Berg M, Toxicol Sci., 2004, 81(2), 316-324; DOI:10.1093/toxsci/kfh216

8. Kumar A, Kumar S and Surendra K, Biochem Eng J., 2005, 22(2), 151-159; DOI:10.1016/j.bej.2004.09.006

9. Latkar M, Swaminathan K and Chakrabarti T, Bioresour Technol., 2003, 88(1), 69-74; DOI:10.1016/S0960-8524(02)00261-4

10. Nasr B, Abdellatif G, Canizares P, Saez C, Lobato J and Rodrigo M A, Environ Sci Technol., 2005, 39(18), 7234-7239; DOI:10.1021/es0500660

11. Arana J, Rodriguez C F, Diaz O G, Melian J A H and Pena J P, Catal Today, 2005, 101(3-4), 261-266; DOI:10.1016/j.cattod.2005.03.006

12. Ahn M Y, Martinez C E, Archibald D D, Zimmerman A R, Bollag J-M and Dec J, Soil Biol Biochem., 2006, 38(5), 1015-1020; DOI:10.1016/j.soilbio.2005.08.016

13. Naik U C, Sivastava S and Thakur I S, Environ Sci Pol Int Res., 2012, 10, 964-1007.

14. Moreno-Castilla C, Carbon, 2004, 42(1), 83-94; DOI:10.1016/j.carbon.2003.09.022

15. Ugurlu M, Gurses A and Acikyildiz M, Micr Mes Mater., 2008, 111(1-3), 228-235; DOI:10.1016/j.micromeso.2007.07.034

16. Baudu M, Guibaud G, Raveau D and Lafrance P, Water Resour Res., 2001, 36, 631-657.

17. Abbassian A and Racionzer P. Analyse Des Marchés Mondiaux, 2012, 1564-2798.

18. Tchakala I, Moctar L, Bawa G, Djaneye-boundjou K S, Doni and Nambo P, Int J Biol Chem Sci., 2012, .6(1), 461-478.

19. Lopez-Ramon M V, Stoeckli F, Moreno-Castilla C and Carrasco-Marin F, Carbon, 1999, 37(8), 1215-1221; DOI:10.1016/S0008-6223(98)00317-0 
20. ASTM D4607- 94. 2006, 100 Barr Harbor Drive, United States.

21. ASTM D2867-09. 2014, West Conshohocken, PA, www.astm.org

22. Langmuir I. J Am Chem Soc., 1918, 40(9), 1361-1403; DOI:10.1021/ja02242a004

23. Yang R T, Imperial College Press, London, United Kingdom, 1987, p. 623.

24. Barrow N J, J Soc Sci., 1978, 29(4), 447-462.

25. Dubinin M M, Zaverina E D and Radushkevich L V, J Phy Chem, 1947, 21, 13511362.

26. Kundu S and Gupta A K, Chem Eng J., 2006, 122(1-2), 93-106; DOI:10.1016/j.cej.2006.06.002

27. Srihari V and Das A, Desalination, 2008, 255(1-3), 220-234; DOI:10.1016/j.desal.2007.07.008

28. Akhtar M, Hasany S, Bhanger M M I and Iqbal S, Chemosphere, 2007, 66(10), 18291838; DOI:10.1016/j.chemosphere.2006.09.006

29. Gaid A, Kaoua F, Mederres N and Khadjsa M, Water SA, 1994, 20(4), 273-278.

30. Ilaboya I R, Oti E O, Ekoh O G and Umukoro L O, Tran J Ener Env., 2013, 4(4), 361-375.

31. Nwabanne J T and Igbakwe P K, J Eng Appl Sci., 2008, 3(11), 829-834.

32. Tchuifon T D R, Anagho S G, Ketcha J M, Nche G N and Ndi J N, Int J Eng Techn Res., 2014, 2(10), 2321-0869.

33. Ndi N J, Ketcha M J, Anagho G S, Ghogomu N J and Belibi B P D, Int J Adv Chem., 2014, 3, 2319-7544.

34. Meldrum B J and Rochester C H, J Chem Sot Faruduy Truns., 1990, 86, 2997.

35. Macias-Garcia A, Venezuela-Calahorro C, Gomez-Serrano V and Espinosa-Ma L, Carbon, 1993, 31(8), 1249-1255; DOI:10.1016/0008-6223(93)90083-M

36. Suh D J, Park T J and Ihm S K, Carbon, 1993, 31(3), 427-435; DOI:10.1016/00086223(93)90130-3

37. O'Reilly J M and Mosher R A, Carbon, 1983, 21(1), 47-51; DOI:10.1016/00086223(83)90155-0

38. Mohamed F S, Khater W A and Mostafa M R, Chem. Eng. J., 2006, 116(1), 47-52; DOI:10.1016/j.cej.2005.10.015

39. Sun Y, Chen J Li A, Liu F and Zhang, Q, React Funct Polym., 2005, 64(2), 63-73; DOI:10.1016/j.reactfunctpolym.2005.03.004

40. Srihari V and Das A, Desalination, 2008, 225(1-3), 220-234; DOI:10.1016/j.desal.2007.07.008

41. Muhamad M, Khan M A and Choong T S Y, J Chem., 2012, 2013, 1666-1672, Article ID 614724. 